\title{
Thymoquinone Reduces Oxidative and Nitrosative Stress in Tongue-tissue of Rats Exposed to Total Cranial Irradiation

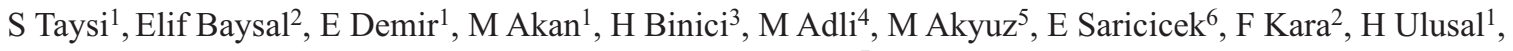 E Karataslioglu?
}

\section{ABSTRACT}

\begin{abstract}
Introduction: Head and neck cancer patients treated with radiotherapy suffer severe side-effects during and following their treatment. Efforts to decrease toxicity of irradiation to normal tissue, organs and cells have led to a search for cytoprotective agent. Investigations for effective and non-toxic compounds with radioprotective capability led to increasing interest in antioxidant such as thymoquinone (TQ).

Objective: The aim of this study was to evaluate the radioprotective effects of $T Q$ on oxidant/antioxidant systems in the tongue-tissue of rats exposed to total cranial irradiation.

Materials and Methods: Thirty-two rats were divided into four groups to test the radioprotective effectiveness of TQ administered by either orogastric tube or intraperitoneal injection. Appropriate control groups were also studied.

Results: Tongue glutathione peroxidase (GSH-Px), glutathione-S-transferase (GST), total superoxide scavenger activity (TSSA), non-enzymatic superoxide scavenger activity (NSSA), and superoxide dismutase (SOD) activities in the control and sham control groups were significantly increased when compared to the irradiation (IR) group and IR plus TQ groups. Nitric oxide (NO $\left.{ }^{\bullet}\right)$, peroxynitrite $\left(\mathrm{ONOO}^{-}\right)$and malondialdehyde (MDA) levels, xantine oxidase (XO) and nitric oxide synthase (NOS) activities significantly increased in the IR group when compared to the control and sham control groups.

Conclusion: Results show that $T Q$ has the radioprotective, antioxidant effects and free radical scavenging activity. Therapy with antioxidants may lead to the increase in the antioxidant defense system and thus, may decrease the clinical symptoms in radiation therapy.
\end{abstract}

Keywords: Antioxidant enzymes, irradiation, oxidative stress, thymoquinone, tongue-tissue.

\section{La Timoquinona Reduce el estrés Oxidativo y Nitrosativo en el tejido de la Lengua de ratas Expuestas a Irradiación Craneal Total}

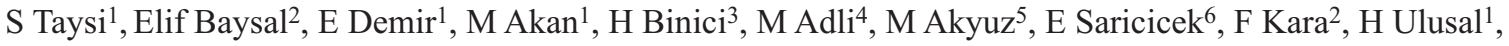 \\ E Karataslioglu?
}

\begin{abstract}
RESUMEN
Introducción: Los pacientes con cáncer de cuello y cabeza tratados con radioterapia sufren efectos secundarios severos durante y después de su tratamiento. Los esfuerzos por disminuir la toxicidad de la irradiación al tejido normal, los órganos y las células han llevado a la búsqueda de un agente citoprotector. Las investigaciones en busca de compuestos eficaces y no tóxicos con capacidad radioprotectora llevó a un creciente interés en antioxidantes tales como la timoquinona (TQ).

Objetivo: El objetivo de este estudio fue evaluar los efectos radioprotectores de la TQ en sistemas oxidantes/antioxidantes en el tejido de la lengua de las ratas expuestas a radiación craneal total.

Materiales y métodos: Treinta y dos ratas fueron divididas en cuatro grupos para probar la efectividad radioprotectora de TQ administrada por inyección intraperitoneal o tubo orogástrico. También se estudiaron los grupos de control apropiados.
\end{abstract}

From: ${ }^{1}$ Department of Medical Biochemistry, ${ }^{2}$ Department of Otolaryngology, Medical School, Gaziantep University, Gaziantep ${ }^{3}$ Department of ${ }^{3}$ Otolaryngology, Medical School, Harran University, Sanliurfa, ${ }^{4}$ Department of Radiation Oncology, Marmara University, Istanbul, ${ }^{5}$ Department of Chemistry, Science and Art Faculty, Kilis 7 Aralik
University, Kilis, ${ }^{6}$ Division of Medical Biochemistry, Dr. Ersin Arslan State Hospital, Gaziantep and ${ }^{7}$ Department of Endodontics, Faculty of Dentistry, Gaziantep, Turkey.

Correspondence: Dr S Taysi, Department of Medical Biochemistry, Gaziantep University Medical School, Gaziantep, Turkey, Fax:+903423603928, e-mail: seytaysi@hotmail.com 


\begin{abstract}
Resultados: La actividad en lengua del glutatión peroxidasa (GSH-Px), glutatión-S-transferasa (GST), la actividad total de barrido de superóxido (ATBS), la actividad no enzimática de barrido de superóxido (ANBS), y las actividades del superóxido dismutasa (SOD) en los grupos de control y control simulado fueron significativamente mayores en comparación con el grupo de irradiación (IR) y los grupos de IR más TQ. Los niveles del óxido nítrico (NO), el peroxinitrito (ONOO-) y el malondialdehído (MDA), las actividades de la xantina oxidasa (XO) y el la sintasa de óxido nítrico (NOS) aumentaron signifi-cativamente en el grupo de IR en comparación con los grupos de control y control simulado.

Conclusión: Los resultados muestran que TQ tiene efectos radioprotectores y antioxidantes y posee una actividad de barrido de radicales libres. La terapia con antioxidantes puede conducir al aumento en el sistema de defensa antioxidante, y asi disminuir los sintomas clínicos en la radioterapia.
\end{abstract}

Palabras claves: Enzimas antioxidantes, irradiación, estrés oxidativo, timoquinona, tejido de la lengua

West Indian Med J 2016; 65 (3): 544

\section{INTRODUCTION}

Radiation therapy is a common and important tool for cancer treatment. Eighty per cent of cancer patients need radiotherapy at some time or other, either for curative or palliative purpose. Radiosensitivity of the normal tissues adjacent to the tumour limits therapeutic gain. Response of the normal tissues to therapeutic radiation ranges from those that cause mild discomfort to others that is life-threatening. The speed at which a response develops varies widely from one tissue to another and often depends on the dose of radiation (1-3). Ionizing radiation is known to generate reactive oxygen species (ROS) in irradiated tissue. Because $80 \%$ of human body weight is water, the majority of the radiation damage result from the aqueous free radicals, generated by the action of radiation on water. Reactive oxygen species also cause injury by reacting with biomolecules such as lipids, proteins and nucleic acids as well as by depleting enzymatic antioxidants such as glutathione peroxidase (GSH-Px), superoxide dismutase (SOD) and/or non-enzymatic antioxidants such as reduced glutathione (GSH), melatonin, Vitamin C, E in the tissue and cells. These reactions take place in tumour as well as normal cells when exposed to radiation (4-6). To control the flux of ROS, aerobic cells have developed their own defense system against free radical attacks, the antioxidant system, which includes enzymatic and non-enzymatic components. The antioxidant system consists of low molecular weight antioxidant molecules such as GSH and of various antioxidant enzymes like superoxide dismutase (SOD) and glutathione peroxidase $(7,8)$.

Nitric oxide $\left(\mathrm{NO}^{\circ}\right)$ is an inorganic free radical produced from L-arginine by a family of isoenzymes called nitric oxide synthases [NOSs] $(9,10)$. Two of them are constitutively expressed and the third is inducible by immunological stimuli. NO', produced by the constitutive enzymes, acts as an important signalling molecule in the cardiovascular and nervous systems, and NO induced by the inducible NOS (iNOS) and generated for prolonged periods by cells of the immune system among others, are cytostatic/cytotoxic for tumour cells and a variety of micro-organisms (10).
Nigella sativa, commonly named as black seed or black cumin, is an annual herb incorporated in diets to promote health and to treat some diseases. Pharmacological and toxicological studies carried out on thymoquinone (TQ), an active component of the volatile oil of black cumin seeds, have reported it to possess diverse pharmacological effect's such as: antioxidant, hepatoprotective, neuroprotective, antidiabetic, anti-inflammatory, nephroprotective, anti-mutagenic, anti-carcinogenic and anti-convulsant activities (11-15).

In this study, we studied the effect of irradiation and addition of TQ on the oxidant/antioxidant system in the tonguetissue of rats exposed to total cranial irradiation. To the best of our knowledge, there is no experimental study that investigates the effect of TQ supplementation on total (enzymatic plus nonenzymatic) superoxide scavenger activity (TSSA), non-enzymatic superoxide scavenger activity (NSSA), SOD, GSH-Px, glutathione-S-transferase (GST), xanthine oxidase (XO), nitric oxide synthase (NOS) activities, nitric oxide $\left(\mathrm{NO}^{\bullet}\right)$, peroxynitrite $\left(\mathrm{ONOO}^{-}\right)$and malondialdehyde (MDA) in the tongue-tissue of the rats receiving ionizing radiation. Therefore, we aimed to investigate the effect of TQ supplementation on oxidant/antioxidant parameters in the tongue-tissue of rats with or without exposure to total cranium irradiation.

\section{SUBJECTS AND METHODS Chemicals}

Thymoquinone, nicotinamide adenine dinucleotide (NADH), reduced glutathione ( $\mathrm{GSH})$, glutathione disulfide reductase, hydrogen peroxide $\left(\mathrm{H}_{2} \mathrm{O}_{2}\right)$, xanthine, xanthine oxidase (XO), nitrobluetetrazolium (NBT), and trichloroacetic acid (TCA) were purchased from Sigma Chemical Co (St Louis, MO, USA).

\section{Rats and experiments}

Thirty-two Sprague-dawley rats, 10-12 weeks old, weighing $200 \pm 25 \mathrm{~g}$ at the time of radiation, were used for the experiment. This study was approved by the local Ethics Committee of the Gaziantep University. The rats were quarantined for 
at least one week before gamma irradiation and fed standard laboratory chow and water ad libitum.

The rats were randomly divided into four equal groups. Group 1 (control group) did not receive TQ or irradiation. Group 2 (Sham control group) did not receive TQ or irradiation, but received ip injections of dimethyl sulfoxide at an equal volume of TQ used in Group 4. Group 3 (IR group) received total cranium 5 Gy gamma irradiation as a single dose plus physiological saline ip. Group 4 (IR plus TQ group) received $50 \mathrm{mg} / \mathrm{kg} /$ day TQ ip injection daily starting 30 minutes before the radiation and continued for 10 days after irradiation (total of 10 days).

Prior to total cranium irradiation, all rats were anesthetized with $80 \mathrm{mg} / \mathrm{kg}$ ketamine $\mathrm{HCl}$ (Pfizer Ilac, Istanbul, Turkey) and placed on a tray in the prone position. The rats in the IR and the IR plus TQ groups received a single dose of 5 Gy irradiation using Cobalt-60 teletherapy unit (Picker, C9, Maryland, NY, USA) from a source-to-surface distance of $80 \mathrm{~cm}$ by $5 \times 5 \mathrm{~cm}$ anterior fields covering the total, while the rats in the control and sham control groups, received sham irradiation. The dose rate was $0.49 \mathrm{~Gy} / \mathrm{min}$. The central axis dose was calculated at a depth of $0.5 \mathrm{~cm}$.

\section{Biochemical analysis}

Ten days after irradiation, all animals were killed by decapitation, their tongues were taken. The tongue-tissues were homogenized in physiological saline solution (IKA-NERKE, GmBH \& CO. KB D-79219, Staufen, Germany). The homogenate was centrifuged at $10000 \mathrm{~g}$ for one hour to remove debris. The clear upper supernatant was collected and all assays were carried out on this fraction. All the procedures were performed at $4{ }^{\circ} \mathrm{C}$.

\section{Determination of TSSA, NSSA and SOD activities}

Total superoxide scavenger activity and NSSA assays, as indicators of tissue antioxidant capacity, were performed on the samples before and after adding trichloroacetic acid (TCA, $20 \%$ ), as described before $(16,17)$. First, TSSA was measured. In this method, xanthine-xanthine oxidase complex produced superoxide radicals that react with nitroblue tetrazolium (NBT) to form a farmazone compound. Total superoxide scavenger activity was calculated by using a blank reaction in which all reagents except the supernatant sample were present and by determining the absorbance of the sample and blank. Second, NSSA activity is measured in TCA-treated fractions prepared by treating part of the sample with a final concentration of $20 \%$ (w/v) TCA solution (to remove all enzymes and proteins), and centrifuged at $5000 \mathrm{x}$ g for 30 minutes. After the elimination of proteins by this procedure, NSSA activity assay was performed in the supernatant fraction. Superoxide dismutase activity was calculated as the difference between TSSA and NSSA. One unit of TSSA, NSSA and SOD was defined as the amount of enzyme protein causing 50\% inhibition in nitrobluetetrazolium reduction rate. Results were expressed as U/mg protein.

\section{Determination of GSH-Px, GST, XO and NOS activities}

Glutathione peroxidase activity was assayed according to Paglia and Valentina (18). In this method, GSH-Px catalyzed the oxidation of glutathione in the presence of tertbutyl hydroperoxide. Oxidized glutathione is converted to the reduced form in the presence of glutathione reductase and NADPH, while NADPH is oxidized to NADP. The reduction in absorbance of NADPH at $340 \mathrm{~nm}$ was measured. The absorbance change per minute and the molar extinction coefficient of NADPH were used to calculate GSH-Px activity. Glutathione peroxidase activity was expressed as IU/mg protein. Glutathione-S-transferase activity of the supernatant was measured by using 1-chloro-2, 4-dinitrobenzene (CDNB) and GSH as described by Habig et al (19). Glutathione-Stransferase activity was expressed as $\mathrm{U} / \mathrm{mg}$ protein. Xantine oxidase activity was measured spectrophotometrically by the formation of uric acid from xanthine through the increase in absorbance at $293 \mathrm{~nm}$ (20). Xantine oxidase activity was expressed as U/mg protein. Nitric oxide synthase activity assay is based on the diazotization of sulfanilic acid by $\mathrm{NO}^{*}$ at acid $\mathrm{pH}$ and subsequent coupling to $\mathrm{N}$-(1-naphthyl) ethylenediamine. To $0.1 \mathrm{~mL}$ of sample, $0.2 \mathrm{~mL}$ of $0.2 \mathrm{M}$ arginine was added and incubated at $37{ }^{\circ} \mathrm{C}$ for one hour. Then, the combination, $0.2 \mathrm{~mL}$ of $10 \mathrm{mM} \mathrm{HCl}, 100 \mathrm{mM}$ sulfanilic acid and 60 $\mathrm{mM} \mathrm{N}$-(1-naphthyl) ethylenediamine was added. After 30 minutes, the absorbance of the sample tube was measured against a blank tube at $540 \mathrm{~nm}$ (21). Results were expressed as $\mathrm{U} / \mathrm{mg}$ protein.

\section{Determination of MDA, $\mathrm{NO}^{\circ}$ and $\mathrm{ONOO}^{-}$levels}

Malondialdehyde, the final product of lipid peroxidation, was determined spectrophotometrically according to a similar method described by Ohkawa et al 1978 (22). Briefly, a mixture of $8.1 \%$ sodium dodecyl sulfate [SDS] $(0.2 \mathrm{~mL}), 20 \%$ acetic acid $(1.5 \mathrm{~mL})$, and $0.9 \%$ thiobarbituric acid $(1.5 \mathrm{~mL})$ was added to the mixture to bring the total volume to $4 \mathrm{~mL}$. This mixture was incubated at $95^{\circ} \mathrm{C}$ for one hour. After incubation, the tubes were left for cooling under cold water and 5 $\mathrm{mL}$ n-buthanol/pyridine $(15: 1, \mathrm{v} / \mathrm{v})$ was added, followed by mixing-up. The samples were centrifuged at $4000 \mathrm{rpm}$ for 10 minutes. The organic phase, accumulated at the top of the tubes, was sampled, and sample absorbances were measured with respect to the blank at $532 \mathrm{~nm}$. The concentration of MDA was calculated using $1.56 \times 10^{5} \mathrm{Mcm}^{-1}$ as molar extinction coefficient. The total thiobarbituric acid-reactive substances were expressed as MDA. Results were expressed as $\mathrm{nmol} / \mathrm{mg}$ protein. Nitric oxide levels in tongue-tissue were measured using the Griess reagent as previously described (23, 24). Griess reagent, the mixture (1:1) of $0.2 \% \mathrm{~N}$-(1-napthyl) ethylenediamine and $2 \%$ sulphanilamide in $5 \%$ phosphoric acid, gives a red-violet diazo dye with nitrite, and the resultant colour was measured at $540 \mathrm{~nm}$. First, nitrate was converted to nitrite using nitrate reductase. The second step was the addition of Griess reagent, which converts nitrite to a deep purple azocompound; photometric measurement of the absorbance 
of $540 \mathrm{~nm}$ determines the nitrite concentration. Results were expressed as $\mu \mathrm{mol} / \mathrm{gr}$ wet weight. $\mathrm{ONOO}^{-}$assay was determined as described $(25,26)$. Ten microlitre of samples was added to $5 \mathrm{mM}$ phenol in $50 \mathrm{mM}$ sodium phosphate buffer $(\mathrm{pH}$ 7.4) to get a final volume of $2 \mathrm{~mL}$. After two hours incubation in a dark place at $37^{\circ} \mathrm{C}, 15 \mu \mathrm{L}$ of $0.1 \mathrm{M} \mathrm{NaOH}$ was added and the absorbance, at wavelength of $412 \mathrm{~nm}$, of the samples were immediately recorded. The yield of nitrophenol was calculated from $\varepsilon=4400 / \mathrm{M} / \mathrm{cm}$. Results were expressed as $\mu \mathrm{mol} / \mathrm{gr}$ wet weight. The protein content was determined as described (27). Biochemical measurements were carried out using a spectrophotometer (Shimadu U 1601, Japan).

\section{Statistical analyses}

Statistical and correlation analyses were undertaken using a one-way variance analysis and Spearman's rank correlation test, respectively. Least significant difference (LSD) multiple range test was used to compare the mean values. Acceptable significance was recorded when $p$-values were $<0.05$. Statistical analysis was performed with Statistical Package for the Social Sciences for Windows (SPSS, version 11.5, Chicago, IL, USA).

\section{RESULTS}

\section{Oxidative parameters}

As seen in Table 1, tongue MDA level and XO activity significantly increased in the IR group when compared to the control and sham control groups. However, when IR group and IR plus TQ group were compared, tongue MDA level and XO activity was significantly increased in the IR group.

\section{Nitrosative parameters}

Tongue NO', $\mathrm{ONOO}^{-}$levels and NOS activity in the IR group significantly increased when compared to the control, sham control, and IR plus TQ groups (Table 2).

\section{Antioxidative parameters}

As seen in Table 3, tongue GSH-Px, GST, TSSA, NSSA, and SOD activities were significantly increased in the control and sham control groups when compared to the IR group and IR plus TQ groups.

\section{Correlation analysis}

In correlation analysis, there were significant negative correlations between tongue-tissue GSH-Px and NO ${ }^{*}$ and GSH-Px and $\mathrm{ONOO}^{-}(\mathrm{r}=-0.75, p<0.05$ and $\mathrm{r}=-0.72, p<0.05)$ in the

Table 1: Oxidantive parameters measured in the tongue-tissues of the rats

\begin{tabular}{|c|c|c|c|c|}
\hline & Control group & $\begin{array}{c}\text { Sham control } \\
\text { group }\end{array}$ & IR group & IR plus TQ group \\
\hline MDA nmol/mg protein & $215.7 \pm 23.8^{d}$ & $174.4 \pm 29.2^{\mathrm{d}, \mathrm{f}}$ & $303.7 \pm 35.2$ & $181.8 \pm 46.4^{\mathrm{d}, \mathrm{g}}$ \\
\hline $\mathrm{XO} \mathrm{U} / \mathrm{g}$ protein & $2.6 \pm 0.7^{\mathrm{d}}$ & $3.6 \pm 1.5^{\mathrm{d}}$ & $14.4 \pm 1.9$ & $5.7 \pm 1.2^{\mathrm{d}, \mathrm{g}, \mathrm{k}}$ \\
\hline
\end{tabular}

$\mathrm{d}: p<0.0001$ vs irradiation group,

f: $p<0.05$, g: $p<0.0001 v s$ control group,

$\mathrm{k}: p<0.01$ vs sham control group.

Table 2: Nitrosative stress parameters measured in the tongue-tissues of the rats

\begin{tabular}{lcccc}
\hline & Control group & $\begin{array}{c}\text { Sham control } \\
\text { group }\end{array}$ & IR group & IR plus TQ group \\
\hline $\mathrm{ONOO}^{-} \mu \mathrm{mol} / \mathrm{gr}$ & $98.3 \pm 16.0^{\mathrm{d}}$ & $103.0 \pm 21.2^{\mathrm{d}}$ & $170.1 \pm 20.7$ & $110.5 \pm 22.8^{\mathrm{d}}$ \\
wet weight & $3.2 \pm 1.3^{\mathrm{c}}$ & $5.6 \pm 2.5^{\mathrm{f}}$ & $6.7 \pm 2.0$ & $4.3 \pm 1.1^{\mathrm{a}}$ \\
$\mathrm{NOS} \mathrm{U}^{\mathrm{m} g}$ protein & $2.4 \pm 1.04^{\mathrm{c}}$ & $3.8 \pm 1.3^{\mathrm{a}}$ & $6.0 \pm 3.3$ & $2.6 \pm 1.08^{\mathrm{b}}$ \\
$\mathrm{NO}^{\bullet} \mu \mathrm{mol} / \mathrm{gr}$ wet weight & & & \\
\hline
\end{tabular}

a: $p<0.05, \mathrm{~b}: p<0.005$, c: $p<0.001, \mathrm{~d}: p<0.0001$ vs irradiation group

Table 3: Antioxidative parameters measured in the tongue-tissues of the rats

\begin{tabular}{lcccc}
\hline & Control group & $\begin{array}{c}\text { Sham control } \\
\text { group }\end{array}$ & IR group & IR plus TQ group \\
& & & \\
\hline TSSA U/mg protein & $4336.9 \pm 239.5^{\mathrm{d}}$ & $4048.6 \pm 505.6^{\mathrm{d}}$ & $3062.2 \pm 145.0$ & $3244.3 \pm 599.8^{\mathrm{g}, \mathrm{n}}$ \\
NSSA U/mg protein & $2879.6 \pm 283.8^{\mathrm{c}}$ & $2799.3^{\mathrm{b}} \pm 561.2$ & $2156.9 \pm 173.1$ & $2259.5 \pm 616.4^{\mathrm{g}, \mathrm{m}}$ \\
SOD U/mg protein & $1457.2 \pm 205.1^{\mathrm{d}}$ & $1249.2 \pm 161.0^{\mathrm{c}}$ & $905.3 \pm 229.7$ & $980.9 \pm 92.6^{\mathrm{g}, \mathrm{m}}$ \\
GSH-Px U/mg protein & $209.6 \pm 34.5^{\mathrm{d}}$ & $169.4 \pm 59.0^{\mathrm{d}, \mathrm{f}}$ & $75.4 \pm 17.9$ & $77.9 \pm 23.1^{\mathrm{g}, \mathrm{n}}$ \\
GST U/mg protein & $1.07 \pm 0.08$ & $0.99 \pm 0.18$ & $1.07 \pm 0.25$ & $1.01 \pm 0.23$ \\
\hline
\end{tabular}

b: $p<0.005, \mathrm{c}: p<0.001, \mathrm{~d}: p<0.0001 v s$ irradiation group,

f: $p<0.05, \mathrm{~g}: p<0.0001$ vs control group,

$\mathrm{m}: p<0.001, \mathrm{n}: p<0.0001$ vs sham control group 
sham control group. However, there were significant positive correlations between tongue-tissue NOS and NO and NOS and $\mathrm{ONOO}^{-}$, and MDA and $\mathrm{XO}(\mathrm{r}=0.9, p<0.005, \mathrm{r}=0.86$, $p<0.005$ and $\mathrm{r}=0.88, p<0.005$, respectively) in the IR group.

\section{DISCUSSION}

Oxygen, while indisputably essential for life, can also participate in the destruction of tissue and/or impair its ability to function normally. Reactive oxygen species, as well as reactive nitrogen species (RNS), are products of normal cellular metabolism and also can be originated by exogenous sources such as carcinogenic compounds and ionizing radiations (28). Reactive oxygen species, RNS including, superoxide anion radical $\left(\mathrm{O}_{2}{ }^{-}\right)$, hydroxyl radical $\left(\mathrm{OH}^{\cdot}\right)$, hydrogen peroxide $\left(\mathrm{H}_{2} \mathrm{O}_{2}\right), \mathrm{NO}^{*}$, peroxynitrite $\left(\mathrm{ONOO}^{-}\right)$play an important role in the aetiology of many diseases $(1,9,10,28)$. It has been estimated that an average person has around 10 000-20 000 free radicals attacking each body cell each day. Reactive oxygen species and reactive nitrogen species are well-recognized for playing a dual role, both deleterious and beneficial, since they can be either harmful or beneficial to living systems (28). Beneficial effects of ROS occur at low/moderate concentrations and involve physiological roles in cellular responses to noxia, as in defense against infectious agents and in the function of a number of cellular signalling systems. One further beneficial example of ROS at low/moderate concentrations is the induction of the mitogenic response. The harmful effect of free radicals causing potential biological damage is termed oxidative and nitrosative stress (29).

In pathological conditions, ROS and RNS are over produced, and this results in lipid peroxidation and oxidative damage. The imbalance between ROS, RNS and antioxidant defense mechanisms leads to oxidative modification in the cellular membrane or intracellular molecules $(30,31)$. Antioxidants are needed to prevent the formation and oppose the actions of ROS and RNS, which are generated in vivo and cause damage on DNA, lipids, proteins and other biomolecules. Endogenous antioxidant defenses are inadequate to prevent this damage completely, thus, diet derived antioxidants are important in maintaining the health (32).

The aim of radiotherapy is to deliver carefully determined doses of ionizing radiation to a defined tumour volume to eliminate tumour cells, while causing minimal injury on surrounding healthy tissue, giving a high quality of life and to prolong survival at a reasonable cost to the patients. However, it is not always possible to keep the normal tissues outside of the treatment field and to avoid side effects and complications of the irradiation $(1,5,33)$. Exposure to high amounts of ionizing radiation results in damage to the haematopoietic, gastrointestinal and central nervous systems, depending on the radiation dose. It is important to protect normal tissues in the treatment field. Radioprotective agents help to protect normal tissues from radiation side effects. However, approved radioprotective agents are expensive and have some severe side effects $(34,35)$. For this reason, to prevent injury caused by radiation on healthy tissue, many investigations related to natural products that have positive effects on oxidant/antioxidant systems have been constructed. Several studies on radioprotective agents are ongoing. To the best of our knowledge, the present study related TQ on tongue-tissue of rats exposed to gamma radiation is the first and important results were obtained.

In this study, we found that irradiation causes a significant decrease in the activity of antioxidant enzymes and also increases oxidant enzymes activities and oxidant parameters in tongue-tissue of rats in IR group when compared to the control and sham control groups. These results are in agreement with the previous studies carried out in different tissues $(1,5$, $30,36)$. Some studies have reported a significant depletion in the antioxidant system accompanied by enhancement of lipid peroxidation after irradiation $(1,5,37)$.

In this study, we found a significant reduction in TSSA, NSSA, SOD, GSH-Px activities, an increase in MDA level, a marker of lipid peroxidation, in rat tongue-tissue in the IR group. However, these changes were not observed in IR plus TQ group when compared to IR group. The reduction in antioxidant enzymes and increase in MDA levels in the IR group may be due to an enhanced utilization of GSH redox cycle as an attempt to detoxify the free radicals generated by irradiation $(1,38)$. The findings obtained in our study showed that premedication with TQ significantly decreases the MDA levels and does not change antioxidant enzyme activities in IR plus TQ group when compared to IR group. Many pharmacological investigations have been done on TQ in recent years. These studies have shown that TQ has antioxidant effect and a free radical scavenging activity, and premedication with TQ protects tissues against oxidative damage induced by a variety of free radical generating agents, including carbon tetrachloride and cisplatin $(39,40)$.

Superoxide dismutase, GSH-Px, and GST are very important antioxidant enzymes that play pivotal role in the elimination of the $\mathrm{O}_{2}{ }^{-}$and $\mathrm{H}_{2} \mathrm{O}_{2}$, and thus, prevent the propagation of lipid peroxidation reactions. In this period, SOD, the first line of defense against oxygen-derived free radicals, catalyses the dismutation of $\mathrm{O}_{2}{ }^{-}$into $\mathrm{H}_{2} \mathrm{O}_{2}$. Hydrogen peroxide can be transformed into $\mathrm{H}_{2} \mathrm{O}$ and $\mathrm{O}_{2}$ by GSH-Px, a selenoprotein that reduces hydroperoxides as well as $\mathrm{H}_{2} \mathrm{O}_{2}$ while oxidizing glutathione (GSSG). A number of potentially toxic electrophilic xenobiotics (such as certain carcinogens, bromobenzene, chlorobenzene) are conjugated to the nucleophilic glutathione (GSH) by GST which is present in high amounts in cell cytosol. Glutathione-S-transferase can also catalyze reactions reducing peroxides like GSH-Px. Reduction of GSSG to GSH is mediated by a widely distributed enzyme GSSG reductase (GRD) that uses NADPH as the reductant. As well known, these enzymes can act as protectors that preserve against the oxidative damage injury induced by $\operatorname{ROS}(1,7,30,36)$. The inhibition of TSSA, NSSA, SOD, GSH-Px activities as well as MDA levels demonstrated in this study after premedication of TQ can probably be explained as a consequence of less 
availability of the substrates for the enzymes as a result of the reported superoxide radical scavenging effect of TQ (41).

In this study, we also showed that the irradiation also causes a significant increase in oxidant enzyme activities in rat tongue-tissue. Radiation-induced increase in XO activity, an oxidant enzyme, was prevented by TQ. Results of this study are in agreement with the results of our previous study with melatonin, L-carnitine and Vitamin E which prevented radiation induced increase in XO activity in rat $(1,3,37)$. Some studies have reported an important increase in lipid peroxidation in different irradiated tissues of rats. The possible mechanisms of irradiation induced increase of oxidative stress include disruption of the mitochondrial respiratory chain leading to leakage from the electron transport chain in rats, depletion of cellular GSH level and decreased activities of antioxidant enzyme and increased activity of oxidant enzyme, ie $\mathrm{XO}$, in rat $(1,30,36)$. Xantine oxidase is an important source of $\mathrm{O}_{2}{ }^{-}$in cells and tissues. It is a member of a group of enzymes known as molybdenum iron-sulfur flavin hydroxylases and catalyses the hydroxylation of purines. Xantine oxidase catalyzes the reaction of hypoxanthine to xanthine and xanthine to uric acid. In both steps, molecular oxygen is reduced, forming the $\mathrm{O}_{2}{ }^{-}$in the first instance and $\mathrm{H}_{2} \mathrm{O}_{2}$ in the second (29). There is growing evidence that $\mathrm{O}_{2}{ }^{-}$radicals produced by $\mathrm{XO}$ are primarily responsible for the cellular deterioration associated with several conditions $(1,38)$. It seems that $\mathrm{O}_{2}{ }^{-}$and $\mathrm{H}_{2} \mathrm{O}_{2}$ are the main sources of radiation-induced free radical production that deplete the cellular GSH level, which has a central role in the antioxidant defense in the cell. Hydrogen peroxide can interact with metal ion or $\mathrm{O}_{2}{ }^{-}$to produce $\mathrm{OH}^{-}$, a very destructive radical. After irradiation accompanied by enhancement of lipid peroxidation, a marked depletion in the antioxidant system was reported in some studies. Normally, the natural defense system can protect against oxidative damage $(1,5,38)$.

Several studies have been reported that ROS and RNS have been implicated in the pathogenesis of a large number of diseases such as cancer, rheumatoid arthritis, infectious diseases, atherosclerosis, and in cataract $(1,7,8,10,13)$. Against these detrimental effects of ROS and RNS, tissues have enzymatic and non-enzymatic defense mechanisms $(8,9)$. Tissue damage starts with lipid radical formation in the cell membrane. This radical first turns into lipid peroxide, and then the damage is completed by the formation of toxic products, such as aldehyde, alkane and MDA (42). Radiation-induced lipid peroxidation is a free radical process. The process of lipid peroxidation is one of oxidative conversion of polyunsaturated fatty acids to several products including MDA and lipid peroxides. Malondialdehyde, because of its high cytotoxicity and inhibitory actions on protective enzymes, acts as a tumour promoter and a co-carcinogenic agent $(10,43,44)$. Malondialdehyde is a well-characterized mutagen that reacts with deoxyguanosine to form a major endogenous adduct found in the DNA of human liver. One result of oxidative stress and lipid peroxidation is the formation of DNA adducts. Because DNA is believed to be the target molecule for carcinogens, endogenous DNA adducts derived from oxidative stress, lipid peroxidation, and other sources have been suggested to contribute to the aetiology of human cancer (45). Also, MDA can react with DNA bases $\mathrm{G}, \mathrm{A}$ and $\mathrm{C}$ to form adducts M1G [pirymido (1, 2a)purin-10(3H)-one)], M1A [ $N^{6}$-(3-oxo-propenyl) deoxyadenosine] and M1C [ $N^{4}$-(3-oxo-propenyl) deoxycytidine], respectively. The major adduct to DNA is M1G. M1G adducts were found in tissue at levels ranging from below the limit of detection to as high as 1.2 adducts per $10^{6}$ nucleosides (which corresponds approximately 6000 adducts per cell). M1G has also been detected in human breast tissue by ${ }^{32} \mathrm{P}$-postlabeling as well as in rodent tissues $(29,45,46)$. In our study, we found that MDA levels in tongue-tissue of rats in the IR group significantly increased when compared to the control, sham control groups. The increases in MDA levels were significantly decreased after TQ premedication in comparison to the IR group. As mentioned above, this is a result of antioxidant effects of the TQ and its free radical scavenging activity.

Several studies have reported that ionizing radiation damages the cells either directly or indirectly through the radiolysis of water and production of free radical. Nitric oxide, a reactive radical, is formed in higher amounts from L-arginine by iNOS in response to ionizing radiation $(43,47)$. Nitric oxide together with other ROS, is known to induce cytotoxicity and cytostasis. Some studies on $\mathrm{NO}^{-}-$and $\mathrm{H}_{2} \mathrm{O}_{2}$ - induced oxidative damage have cited similarities between the two chemicals in their enzymatic generation, chemical interaction with macromolecules and resulting cytotoxicity $(44,48)$. Agrawal et al (49) in their study carried out in animals reported that NO* levels induced by radiation were significantly higher in the liver of tumour-bearing animals when compared to the non-tumour-bearing control group of animals. In this study, when rats were exposed to single dose 5 Gy gamma irradiation, we found that $\mathrm{NO}^{-}$and $\mathrm{ONOO}^{-}$levels and the NOS activity in IR group significantly increased in the tongue-tissue of rats when compared to control, and sham control groups. Premedication with TQ significantly decreased these parameters in IR plus TQ group compared to the IR group.

Under conditions of nitrosative stress induced by irradiation, $\mathrm{NO}^{-}$is often produced; it reacts rapidly with $\mathrm{O}_{2}{ }^{-}$to form $\mathrm{ONOO}^{-}(38,44,50)$, which in itself is cytotoxic and readily decomposes into the highly reactive and toxic $\mathrm{OH}^{-}$and nitrogen dioxide $\left(\mathrm{NO}_{2}\right)$. $\mathrm{ONOO}^{-}$is much more reactive than $\mathrm{NO}^{\circ}$ and $\mathrm{O}_{2}{ }^{-}$which cause diverse chemical reactions in biological systems including nitration of tyrosine residues of proteins, triggering of lipid peroxidation, inactivation of aconitases, inhibition of the mitochondrial electron transport, oxidation of biological thiol compounds, and damage to DNA $(44,45,51)$. Reactive nitrogen species also causes DNA damage, which result in mutation. Increase in RNS formation and decrease in antioxidant enzymes lead to oxidative DNA injury.

This damage is primarily caused due to formation of ONOO. A study done by Inoue et al (52) has been reported that SIN-1, a donor which is capable of generating both $\mathrm{NO}^{*}$ and 
$\mathrm{O}_{2}^{--}$, oxidizes guanine to 8-hydroxydeoxyguanosine (OH-dG). Thus, there occurs a balance between oxidative and nitrosative stress (53). Many studies have also been reported that NO enhances the oxidative stress caused by $\mathrm{H}_{2} \mathrm{O}_{2}$ and also reacts with other radicals such as lipid peroxides $(10,44,53)$. The endogenous production of NO causing DNA damage generates both oxidative and nitrosative stress (53).

In conclusion, we found increased nitrosative and oxidative stress and decreased antioxidant parameters in tonguetissues of rats in IR group in comparison to the other groups. This is the first study that investigates the effect of thymoquinone on the oxidant/antioxidant system in the irradiated tongue-tissue of the rats. In view of the data obtained in this study, by reducing the formation of $\mathrm{NO}^{\circ}, \mathrm{ONOO}^{-}$and $\mathrm{MDA}$, an indicator of lipid peroxidation, and decreasing XO, NOS activities, TQ has shown antioxidant effects and a free radical scavenging activity and reduced oxidative stress in the tonguetissue of rats exposed to gamma irradiation. Thymoquinone may be a beneficial agent in protection against ionizing radiation-related tissue injury. In addition, further studies are required to determine the potential value of specific antioxidant nutrients during radiotherapy.

\section{REFERENCES}

1. Taysi S, Memisogullari R, Koc M, Yazici AT, Aslankurt M, Gumustekin $\mathrm{K}$ et al. Melatonin reduces oxidative stress in the rat lens due to radiationinduced oxidative injury. Int J of Radiat Biol 2008; 84: 803-8.

2. Nair CK, Parida DK, Nomura T. Radioprotectors in radiotherapy. J Radiat Res 2001; 42: 21-37.

3. Kocer I, Taysi S, Ertekin MV, Karslioglu I, Gepdiremen A, Sezen O et al. The effect of L-carnitine in the prevention of ionizing radiation-induced cataracts: a rat model. Graefe's archive for clinical and experimental ophthalmology $=$ Albrecht von Graefes Archiv fur klinische und experimentelle Ophthalmologie 2007; 245: 588-94.

4. Shirazi A, Ghobadi G, Ghazi-Khansari M. A radiobiological review on melatonin: a novel radioprotector. J Radiat Res 2007; 48: 263-72.

5. Karslioglu I, Ertekin MV, Taysi S, Kocer I, Sezen O, Gepdiremen A et al. Radioprotective effects of melatonin on radiation-induced cataract. J Radiat Res 2005; 46: 277-82.

6. Karslioglu I, Ertekin MV, Kocer I, Taysi S, Sezen O, Gepdiremen A et al. Protective role of intramuscularly administered vitamin E on the levels of lipid peroxidation and the activities of antioxidant enzymes in the lens of rats made cataractous with gamma-irradiation. Eur J Ophthalmol 2004; 14: $478-85$.

7. Aktan B, Taysi S, Gumustekin K, Bakan N, Sutbeyaz Y. Evaluation of oxidative stress in erythrocytes of guinea pigs with experimental otitis media and effusion. Ann Clin Lab Sci 2003; 33: 232-6.

8. Taysi S. Oxidant/antioxidant status in liver tissue of vitamin B6 deficient rats. Clin Nutr 2005; 24: 385-9.

9. Aktan B, Taysi S, Gumustekin K, Ucuncu H, Memisogullari R, Save K et al. Effect of macrolide antibiotics on nitric oxide synthase and xanthine oxidase activities, and malondialdehyde level in erythrocyte of the guinea pigs with experimental otitis media with effusion. Pol J Pharmacol 2003; 55: 1105-10.

10. Taysi S, Uslu C, Akcay F, Sutbeyaz MY. Malondialdehyde and nitric oxide levels in the plasma of patients with advanced laryngeal cancer. Surg Today 2003; 33: 651-4.

11. Gali-Muhtasib H, Roessner A, Schneider-Stock R. Thymoquinone: a promising anti-cancer drug from natural sources. Int J Biochem Cell Biol 2006; 38: 1249-53.

12. Ustun K, Taysi S, Sezer U, Demir E, Baysal E, Demir T et al. Radio-protective effects of Nigella sativa oil on oxidative stress in tongue tissue of rats. Oral Dis 2014; 20: 109-13.
13. Ahlatci A, Kuzhan A, Taysi S, Demirtas OC, Alkis HE, Tarakcioglu M et al. Radiation-modifying abilities of Nigella sativa and thymoquinone on radiation-induced nitrosative stress in the brain tissue. Phytomedicine 2014; $21: 740-4$

14. Taysi S, Abdulrahman ZK, Okumus S, Demir E, Demir T, Akan M et al. The radioprotective effect of Nigella sativa on nitrosative stress in lens tissue in radiation-induced cataract in rat. Cutan Ocul Toxicol 2015; 34: $1-6$.

15. Cikman O, Taysi S, Gulsen MT, Demir E, Akan M, Diril H et al. The radio-protective effects of caffeic acid phenethyl ester and thymoquinone in rats exposed to total head irradiation. Wien Klin Wochenschr 2015; 127: $103-8$.

16. Durak I, Canbolat O, Kacmaz M, Ozgen G, Ozturk HS. Antioxidant interferences in superoxide dismutase activity methods using superoxide radical as substrate. Clin Chem Lab Med 1998; 36: 407-8.

17. Sun Y, Oberley LW, Li Y. A simple method for clinical assay of superoxide dismutase. Clin Chem 1988; 34: 497-500.

18. Paglia DE, Valentine WN. Studies on the quantitative and qualitative characterization of erythrocyte glutathione peroxidase. J Lab Clin Med 1967; 70: 158-69.

19. Habig WH, Pabst MJ, Jakoby WB. Glutathione S-transferases. The first enzymatic step in mercapturic acid formation. J Biol Chem 1974; 249: 7130-9.

20. Hashimoto S. A new spectrophotometric assay method of xanthine oxidase in crude tissue homogenate. Anal Biochem 1974; 62: 426-35.

21. Durak I, Ozturk HS, Elgun S, Cimen MY, Yalcin S. Erythrocyte nitric oxide metabolism in patients with chronic renal failure. Clin Nephrol 2001; 55: 460-4.

22. Ohkawa H, Ohishi N, Yagi K. Reaction of linoleic acid hydroperoxide with thiobarbituric acid. J Lipid Res 1978; 19: 1053-7.

23. Moshage H, Kok B, Huizenga JR, Jansen PL. Nitrite and nitrate determinations in plasma: a critical evaluation. Clin Chem 1995; 41: 892-6.

24. Bories PN, Bories C. Nitrate determination in biological fluids by an enzymatic one-step assay with nitrate reductase. Clin Chem 1995; 41: 904-7.

25. Vanuffelen BE, Van Der Zee J, De Koster BM, Vansteveninck J, Elferink JG. Intracellular but not extracellular conversion of nitroxyl anion into nitric oxide leads to stimulation of human neutrophil migration. The Bioch J 1998; 330: 719-22.

26. Al-Nimer MS, Al-Ani FS, Ali FS. Role of nitrosative and oxidative stress in neuropathy in patients with type 2 diabetes mellitus. J Neurosci Rural Pract 2012; 3: 41-4.

27. Bradford MM. A rapid and sensitive method for the quantitation of microgram quantities of protein utilizing the principle of protein-dye binding. Anal Biochem 1976; 72: 248-54.

28. Valko M, Izakovic M, Mazur M, Rhodes CJ, Telser J. Role of oxygen radicals in DNA damage and cancer incidence. Mol Cell Biochem 2004; 266: 37-56.

29. Valko M, Rhodes CJ, Moncol J, Izakovic M, Mazur M. Free radicals, metals and antioxidants in oxidative stress-induced cancer. Chem Biol Interact 2006; 160: 1-40.

30. Emin Buyukokuroglu M, Taysi S, Koc M, Bakan N. Dantrolene protects erythrocytes against oxidative stress during whole-body irradiation in rats. Cell Biochem Funct 2003; 21: 127-31.

31. Taysi S, Cikman O, Kaya A, Demircan B, Gumustekin K, Yilmaz A et al. Increased oxidant stress and decreased antioxidant status in erythrocytes of rats fed with zinc-deficient diet. Biol Trace Elem Res 2008; 123: 161-7.

32. Halliwell B. Antioxidants in human health and disease. Annu Rev Nutr 1996; 16: 33-50.

33. Ertekin MV, Kocer I, Karslioglu I, Taysi S, Gepdiremen A, Sezen O et al. Effects of oral Ginkgo biloba supplementation on cataract formation and oxidative stress occurring in lenses of rats exposed to total cranium radiotherapy. Jpn J Ophthalmol 2004; 48: 499-502.

34. Hu Y, Guo DH, Liu P, Cao JJ, Wang YP, Yin J et al. Bioactive components from the tea polyphenols influence on endogenous antioxidant defense system and modulate inflammatory cytokines after total-body irradiation in mice. Phytomedicine 2011; 18: 970-5. 
35. Hosseinimehr SJ. Trends in the development of radioprotective agents. Drug Discov Today 2007; 12: 794-805.

36. Koc M, Taysi S, Emin Buyukokuroglu M, Bakan N. The effect of melatonin against oxidative damage during total-body irradiation in rats. Radiat Res 2003; 160: 251-5.

37. Taysi S, Okumus S, Ezirmik S, Uzun N, Yilmaz A, Akyuz M et al. The Protective Effects of L-Carnitine and Vitamin E in Rat Lenses in Irradiation-Induced Oxidative Injury. Adv Clin Exp Med 2011; 20: 15-21.

38. Okumus S, Taysi S, Orkmez M, Saricicek E, Demir E, Adli M, Al B. The effects of oral Ginkgo biloba supplementation on radiation-induced oxidative injury in the lens of rat. Pharmacogn Mag 2011; 7: 141-5.

39. Nagi MN, Alam K, Badary OA, al-Shabanah OA, al-Sawaf HA, alBekairi AM. Thymoquinone protects against carbon tetrachloride hepatotoxicity in mice via an antioxidant mechanism. Biochem Mol Biol Int 1999; 47: 153-9.

40. Badary OA, Nagi MN, al-Shabanah OA, al-Sawaf HA, al-Sohaibani MO, al-Bekairi AM. Thymoquinone ameliorates the nephrotoxicity induced by cisplatin in rodents and potentiates its antitumor activity. Can J Physiol Pharmacol 1997; 75: 1356-61.

41. Mansour MA, Nagi MN, El-Khatib AS, Al-Bekairi AM. Effects of thymoquinone on antioxidant enzyme activities, lipid peroxidation and DT-diaphorase in different tissues of mice: a possible mechanism of action. Cell Biochem Funct 2002; 20: 143-51.

42. Polat B, Suleyman H, Alp HH. Adaptation of rat gastric tissue against indomethacin toxicity. Chem Biol Interact 2010; 186: 82-9.

43. Taysi S, Koc M, Buyukokuroglu ME, Altinkaynak K, Sahin YN. Melatonin reduces lipid peroxidation and nitric oxide during irradiation-induced oxidative injury in the rat liver. J Pineal Research 2003; 34: 173-7.
44. Bakan E, Taysi S, Polat MF, Dalga S, Umudum Z, Bakan N et al. Nitric oxide levels and lipid peroxidation in plasma of patients with gastric cancer. Japanese journal of clinical oncology 2002; 32: 162-6.

45. Wang MY, Dhingra K, Hittelman WN, Liehr JG, deAndrade M, Li DH. Lipid peroxidation-induced putative malondialdehyde-DNA adducts in human breast tissues. Cancer Epidem Biomar 1996; 5: 705-10.

46. Marnett LJ. Lipid peroxidation-DNA damage by malondialdehyde. Mutat Res 1999; 424: 83-95.

47. Tsuji C, Shioya S, Hirota Y, Fukuyama N, Kurita D, Tanigaki T et al. Increased production of nitrotyrosine in lung tissue of rats with radiationinduced acute lung injury. Am J Physiol Lung Cell Mol Physiol 2000; 278: L719-25.

48. Abu-Shakra A, McQueen ET, Cunningham ML. Rapid analysis of basepair substitutions induced by mutagenic drugs through their oxygen radical or epoxide derivatives. Mutat Res 2000; 470: 11-8.

49. Agrawal A, Chandra D, Kale RK. Radiation induced oxidative stress: II - Studies in liver as a distant organ of tumor bearing mice. Mol Cell Biochem 2001; 224: 9-17.

50. Babicova A, Havlinova Z, Pejchal J, Tichy A, Rezacova M, Vavrova J et al. Early changes in L-arginine-nitric oxide metabolic pathways in response to the whole-body gamma irradiation of rats. Int J Radiat Biol 2011; 87: 1067-73.

51. Gilad E, Cuzzocrea S, Zingarelli B, Salzman AL, Szabo C. Melatonin is a scavenger of peroxynitrite. Life Sci 1997; 60: PL169-74.

52. Inoue $\mathrm{S}$, Kawanishi $\mathrm{S}$. Oxidative DNA damage induced by simultaneous generation of nitric oxide and superoxide. FEBS Lett 1995; 371: 86-8.

53. Habib S, Ali A. Biochemistry of nitric oxide. Indian J Clin Biochem: IJCB 2011; 26: 3-17. 